\title{
Problems of Providing Travel Services to Inclusive Aviation Tourists: World and Ukrainian experience
}

\author{
Natalyya Bielousova ${ }^{1 \star}$, Olha Lyubitseva ${ }^{2}$, Olha Skorostetska ${ }^{3}$, Olena Boiko ${ }^{4}$ \\ ${ }^{1}$ Department of Land Planning and Cadastre National Aviation University, Kyiv, Ukraine \\ belousova-69@ukr.net - (iD) 0000-0002-5829-1467 \\ ${ }^{2}$ Department of Regional Studies and Tourism, National Aviation University, Kyiv, Ukraine \\ loa13@ukr.net-(D) 0000-0002-8508-9395 \\ ${ }^{3}$ Department of Regional Studies and Tourism, Taras Shevchenko National University of Kiev, Ukraine \\ lilamirinda@icloud.com - (D) 0000-0002-1722-8250 \\ ${ }^{4}$ Department of Land Planning and Cadastre, Taras Shevchenko National University of Kiev, Ukraine \\ boyko_lena@ukr.net - (DD 0000-0001-8654-9392
}

\section{Abstract}

The article examines the features of the development of the modern world tourism market and the problems of providing tourism services to inclusive aviation tourists. The world experience of air transportation of inclusive tourists in different countries is analysed. Analytical material is offered, reflecting the problems of airlines work in transporting tourists from inclusive groups. The prospects of the infrastructure of Ukrainian airports are assessed; problems associated with air services for people with different categories of inclusion, especially people with disabilities, are identified. The emphasis is on developing tourism in Ukraine as a segment of the Ukrainian economy within the framework of studying the issue of development and implementation of inclusive tourism in Ukraine. In this regard, the legal regulation of relations between representatives of air transportation and an inclusive tourist, who requires special conditions of movement, which is usually associated with physical health (people with heavyweight, older adults, pregnant women) or disability, are relevant. The research identified the problems and suggested solutions that relate to tourist services in developing a consistent, logical and compromise approach to providing comfortable services for air travel for people with disabilities and passengers of other inclusive categories.
\end{abstract}

\section{Keywords}

Inclusive air tourists,

Travel services,

Air travel,

People with disabilities

\section{Time Scale of Article}

Received 5 May 2021

Revised until 21 June 2021

Accepted 21 June 2021

Online date 27 June 2021

\section{Introduction}

Tourism, in recent decades, was a powerful economic component that has been actively developing in the world, gaining constant momentum, introducing the best innovative technologies and accumulating significant financial flows, which for some countries were the primary source of income.

According to the World Tourism Organization (UNWTO Tourism Highlights, 2018), tourism has become the

*: Corresponding Author Natalyya Bielousova, belousova-69@ukr.net DOI: 10.23890/IJAST.vm02is01.0105 leading sector of the economy, accounting for $10 \%$ of world GDP and 7\% of world exports (Bielousova, 2017).

For Ukraine, the tourism sector is one of the essential segments of the economic complex, supporting the economic development of the country and enabling Ukraine's competitive access to European and international tourism markets. (Bielousova, 2019)

Despite the significant recession in the global economy associated with the COVID-19 pandemic, tourism remains a multifunctional sphere of providing various services, including tourist air flights. People with 
inclusion require special attention to themselves (from the English inclusion - inclusion): persons with disabilities of various nosology, old people with physical and psychological health characteristics, people with "war syndrome", large families, pregnant women and other members of society (Bielousova and Skorostetska, 2020).

For such categories of inclusive tourists, a certain accessible environment of existence is formed. Therefore, we propose to call an inclusive environment and the main task of creating comprehensive accessibility, comprehensive adaptation, and barrierfree.

The popularity of inclusive tourism is dynamically developing and increasing due to the continuous growth of the relative and absolute number of people of few mobile groups, people with various nosologies and types of disabilities worldwide and in Ukraine.

Integrating people with inclusion (people with disabilities) into Ukrainian society, their social activity and professional self-realisation remain practically unclaimed. And so far, there is only talk about inclusively accessible modes of transport.

In this context, a logical and consistent action seems to us to be a regular scientifically grounded monitoring of both the global and the national system of tourist services associated with the provision of a wide range of tourist services for all categories of people with inclusion, including transport services using the example of air transportation. Considering the popularity of air transport in the world, it must be stated that many companies create favourable conditions for passengers with inclusive travel, which means they are included in the program of creating an inclusive environment.

Therefore, the purpose of this article is to analyse the level of development of inclusive tourism, as a modern segment of the tourism industry in Ukraine (Bielousova, 2019), in the process of providing travel services for air transportation of people with inclusion, especially people with disabilities, taking into account the world experience of travel by air.

\section{Literature Review}

Scientists from different countries are engaged in inclusive accessibility and comfortable life, proposing their own algorithm for introducing inclusive tourism to create a comfortable environment for those who have disabilities or need social assistance.

Since 2006, the inclusion problems have been considered both by foreign experts in various fields and fields of science and by scientists from Ukraine and neighbouring countries. Various foreign scientific schools offer many research papers (Konanova, 2019; Le Man, 2011; Mezhevaya et al., 2015; Naumenko et al., 2015) highlighting the problems of theoretical substantiation and practical application of methods, techniques, developments that are associated with inclusive tourism, where tourism acts as an accessible, barrier-free environment that helps people with disabilities adapt (Bielousova, 2019).

Many authors associate tourism with sports (the institution of social tourism includes sports tourism), social protection (the institution of social protection includes rehabilitation tourism) and education (the educational institution includes children) as social institutions directly related to tourism (youth tourism) (Bielousova, 2020), separately considering rehabilitation or medical assistance (Bielousova, 2017).

The article also highlighted the issues of comfortable passenger transportation under the environmental conditions for the operation of air transport (State Aviation Administration of Ukraine, 2018) and focused on scientific and practical research of scientists of the National Aviation University in Kyiv (Yun and Marintseva, 2014; Zaporozhets and Synylo 2012; Zaporozhets, 2014; Boyko and Prusov, 2018).

At the formation and scientific substantiation stage, fundamental research on the development and implementation of inclusive tourism in Ukraine will be based on a comprehensible application methodology and a mechanism for the practical application of modern methods of socialisation of people with inclusion through tourism services. (Bielousova, 2019)

\section{Research Methodology}

The inquiry of the integration process and the practical solution of the problems of integration into society of persons with inclusion, and first of all people with disabilities, the development of its principles, mechanisms, key directions and the justification of practical recommendations, is an essential and urgent task of any society. (Bielousova, 2019)

Therefore, it seems logical to us to analyse the methodological research in air transportation, including tourism.

The methodological basis for the study of air transportation as a tourist product is made up of general scientific, analytical, and predictive methods and methodological techniques that provide a conceptual vision of the problem of air transportation of tourist flows, taking into account the specifics and transport policy of the country, the specifics and rules for the movement of tourists, as well as compliance with international standards for the transportation of air tourists.

System analysis allows us to consider any situation as a kind of object for study with a wide range of internal and external cause-and-effect relationships (Bielousova, 2019) which in this article are presented in the form of 
statistical data of quantitative and qualitative indicators of internal and external air transportation of passengers, with an emphasis on tourist transportation by air.

For the cost-effective transport of tourists, it is important to assess the optimal costs for both regular passengers and inclusive tourists. Therefore, the economic models of air transportation of tourists, taking into account the existing factors of market capacity, make it possible to determine the most rational strategies for using air transport, taking into account government funding for those companies that expand the range of services for categories of people with inclusion.

One of the popular methods of modern society is the information accessibility method. Considering a wide range of information sources, the task of a tourist or aviation enterprise is to make high-quality and reliable self-advertising about the services offered.

\section{Analysis \& Discussion}

Tourism for people with disabilities, including international, is an urgent problem since, according to a study by the World Health Organization (2019), 785 million people aged 15 years and older live with disabilities (UNWTO Tourism Highlights, 2018), more than 1 billion people with disabilities, equivalent to $15 \%$ of the world's population. Moreover, this number is expected to grow in the coming years (Bielousova, 2017).

Demographic data also indicate that the number of older people and people with disabilities who want to travel by air will increase significantly in the future (UNWTO Tourism Highlights, 2018).

In the countries of the world, organising international tourism and the availability of travel for people with disabilities has already developed.

Based on this, we consider tourism in Ukraine a paradigm for sustainable development of the country, where tourism works for the stable development of regions, and not vice versa. In addition, through the prism of tourism activities, it is possible to stabilise the economic situation in the country, given the huge regional tourism potential, which includes transport infrastructure, in particular air travel. (Bielousova, 2019)

The existing international framework for inclusive tourism development include the UN Convention on the Rights of Persons with Disabilities, the 2030 Agenda for Sustainable Development, which provides targeted action in providing a variety of social services by businesses, including in the transport sector. In addition, the UN Framework Convention recognises that accessibility, freedom of movement and personal mobility are fundamental rights of persons with disabilities and that respect for these rights requires the participation of a wide range of different stakeholders. (Bielousova, 2017)
These and other documents apply to air transportation, being the regulators of consumer relations.

Despite the existence of such international legal norms and guidelines, the aviation industry is suffering the effects of a steady increase in the number of national/regional policies for people with inclusion. Again, the category of people with disabilities stands out. Unfortunately, these strategies can often be either inconsistent or in direct conflict with each other, leading to complications in the operation of airlines and confusion for passengers with disabilities.

To support the creation of consistent rules for ensuring accessibility and the provision of high-quality services, national air carriers develop principles and methods of tourism services, following national legislation and within the national policy of a particular country concerning people with inclusion, people with disabilities.

The rules of modern transportation require each person with a disability to coordinate their transportation with the airline and have a personal escort, which does not guarantee service by the airline - the carrier of people with disabilities. If earlier the airline could refuse transportation to a disabled person, citing the lack of "special conditions of transportation", today every selfrespecting air carrier offers a certain range of services for the transportation of people of inclusive categories.

For tourists in wheelchairs, airports are equipped with travelators, special elevators, hygiene rooms (WC), accessible passages through the airport, special transport is offered for transporting tourists to the airport. Such tourists usually check-in for the flight first of all in the main queue or a separate area. One or more seats are retracted (folded) in the tail section of the aircraft. A disabled passenger gets on and off the plane last.

For people who do not see, an adaptable special floor covering is offered, which makes it possible to coordinate the movement of a person. When escorting a blind person on board an aircraft, special lifts are often used.

The studies carried out on the issue of safe air transportation of inclusive passengers made it possible to both confirm and refute the influence of the listed factors. Therefore, the question arises of creating a unified model of tourist services for inclusive air passengers. Furthermore, if we talk about people with disabilities, then the comfort of movement and the level of accessibility is a priority for them.

The problem of providing tourism services to inclusive aviators can be viewed from several aspects. Firstly, the process of providing air services for passengers with different inclusions and disabilities has clear rules spelt out in international and state regulatory documents, which are discussed, supplemented and revised over time. 
To understand this issue, a clear understanding is needed for who can be referred to as inclusive tourists and why there are several problems associated with providing various kinds of social and tourist services for this category of people.

In comparison with the already well-known international typification of people with inclusion (older adults, overweight people, pregnant women, people with disabilities, etc.), in Ukraine, the author's typing is proposed (Bielousova, 2020), the editing of which is dictated by the socio-economic development in the country, the level of social security of Ukrainians, as well as modern historical events.

We include the following low-mobility groups of the population as an inclusive society: social group (Chernobyl victims, pensioners, pregnant women, large families and others); a group of people with disabilities (various groups of disabilities and nosologies) people with a "war syndrome" (Afghans, ATO military zones, migrants, persons with psychological trauma, war children, war veterans and others) (Fig. 1).

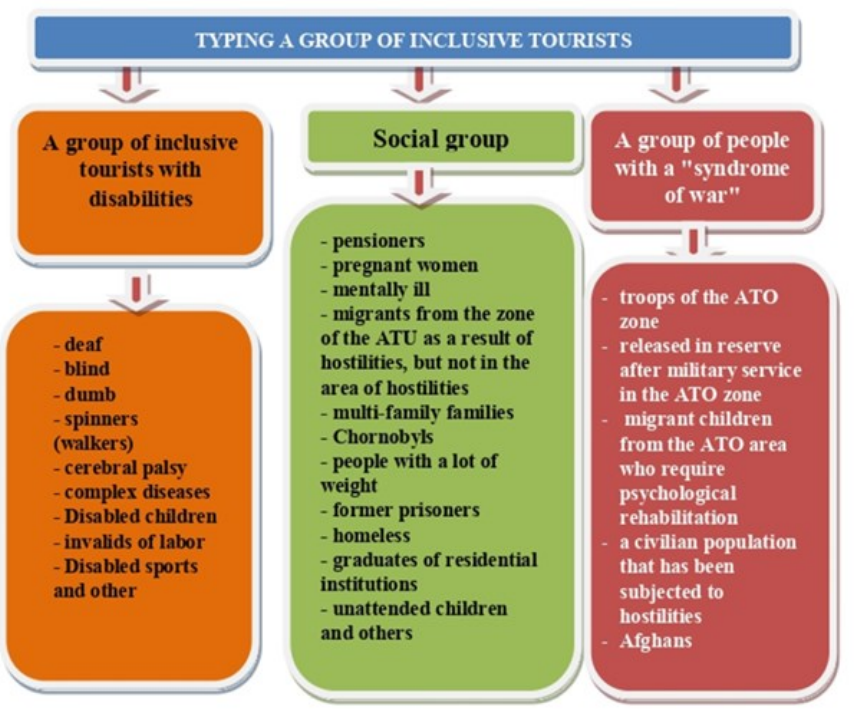

Fig. 1. The scheme of typing groups of inclusive tourists in Ukraine (Bielousova, 2020)

The most vulnerable in terms of socialisation and creation of a barrier-free comfortable environment are people with disabilities. Back in 2006, the United Nations (UN) adopted the Convention on the Rights of Persons with Disabilities (CRPD), making states responsible for supporting and protecting the rights of people with disabilities. (Bielousova,2018)

And the International Civil Aviation Organization (ICAO) has established International Standards and Recommended Practices (SARPs) in Appendix 9 to the Chicago Convention concerning the facilitation of formalities for persons with disabilities in air transport (Bielousova, 2017; Le, 2011)
The principles (main provisions) of this Convention are as follows:

- Respect for a person's inherent dignity, his independence, including the freedom to make his own choice, and independence.

- Non-discrimination (equal treatment of all).

- Full and effective involvement and inclusion in society.

- Respect for the characteristics of persons with disabilities and their acceptance as a component of human diversity and part of humanity.

- Equality of opportunity.

- Accessibility (free access to vehicles, places and information and the impossibility of denying access due to disability) (Boyko, 2018).

Economically developed countries in Europe (France, Germany, Great Britain, Austria, Sweden, Norway and others) and the world (USA, Japan, China, Turkey, Singapore and others) are considering the possibility of developing a new strategic policy related to ensuring accessibility in the aviation industry (Airbus, 2019).

In the air travel industry, the erection of inclusive accessibility barriers has a historical rationale:

1. Concern for the safety of the disabled person himself, incl. in emergency situations.

2. Concern for the safety of other passengers, whom a person with a disability can potentially interfere with during evacuation.

3. The need to provide additional types of services to people with disabilities, as well as other inclusive categories (people with heavy weight, pregnant women, elderly people, etc.) from airlines and the airport (Le Man, 2011).

In the last decade, the level of service in air transport has improved: it has become more comfortable, innovative and technologically advanced. As a result, the world's leading airports position themselves as universal organisations to provide air services. Air carriers compete in the passenger air transportation market to cover all categories of passengers, including those with inclusion.

For the sixth year in a row (2011-2019), Singapore Changi International Airport was recognised as the best airport. The TOP-5 also includes South Korean Incheon, Tokyo Haneda, airports in Hong Kong and Doha (Qatar) (AON, 2020; Boyko, 2018).

Among European airports, the top ten were German Munich (sixth), British London Heathrow (8th), Swiss Zurich (9th) and German Frankfurt (10th) (Boyko, 2018).

If we take the traffic statistics of the ten busiest airports in the world for 2016 and 2019, we can see a steady increase in passenger traffic, and proportionally in different countries of the world, Fig. 2 (Boyko, 2018). 


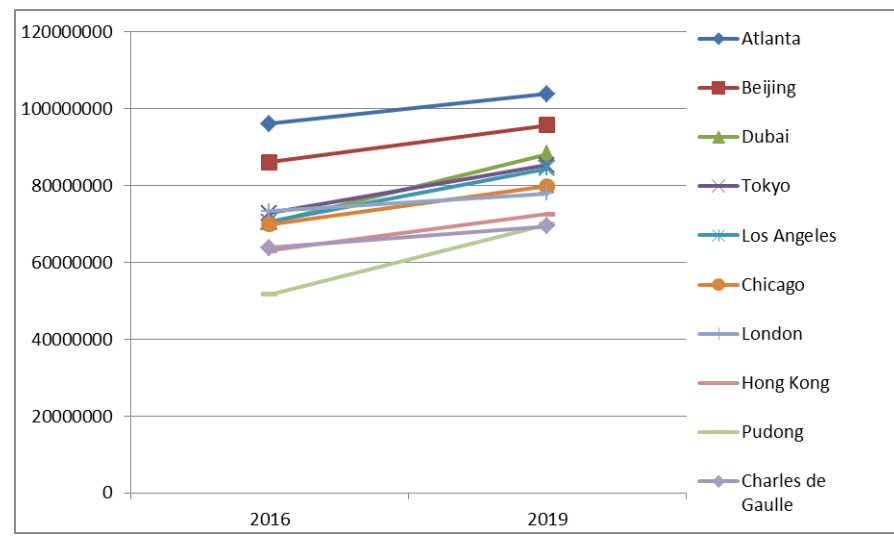

Fig. 2. Passenger traffic of ten most secured airports in the world for 2016 and 2019 (Boyko, 2018)

The main flows of air transport passengers include inclusive tourists, who make up $0.7 \%$ of the total number of air carriers in the world (AON, 2020).

According to statistics, in 2016, the ranking of the 100 busiest airports in the world was headed by Lisbon (Portugal) airport, with passenger traffic of 18142000 people, in the fiftieth line of the rating was Domodedovo airport (Moscow, Russia) with passenger traffic of 33108 000 people, and the tenth - by Hong Kong airport (China) $63,122,000$ people, and the first place was occupied by the airport in the city of Atlanta (USA) with passenger traffic of 96,179,000 people (Boyko, 2018).

In 2019, the fiftieth place was taken by Sheremetyevo airport (Moscow, Russia) with passenger traffic of $40,092,806$ people, 10th place was taken by Charles de Gaulle airport (France) with passenger traffic of $69,471,000$ people, and the first place was occupied by the airport of Atlanta (USA) with a record 103,902,992 passengers. If we compare with the passenger traffic and the workload of the airport of Ukraine "Boryspil", the figures will be ten times lower (Boyko, 2018).

According to the State Aviation Service, in April 2021, there are 20 airports, 11 civil aviation airfields, 2 heliports and 42 landing sites in Ukraine (SSU, 2017; Boyko, 2018).

The largest international airports in Ukraine are Boryspil (Kyiv), Kyiv (Zhulyany), Odessa, Lviv, Kharkov, Dnieper and Zaporizhzhia (Boyko, 2018).

It should be noted that $98 \%$ of total passenger traffic and freight traffic are concentrated in these seven leading airports. In comparison, the fate of the country's main airport «Boryspil» in the total volume of passenger traffic decreased from $67 \%$ in 2016 to $64 \%$ in 2019 . On the other hand, it immediately increased the share of the airports «Kyiv (Zhulyany)», «Lviv» and «Kharkov» (Boyko, 2018) slightly.

According to the State Aviation Administration of Ukraine, the ratio of the leading airports in the total volume of passenger traffic is shown in Figure 3 (SSU, 2017; Boyko, 2018).

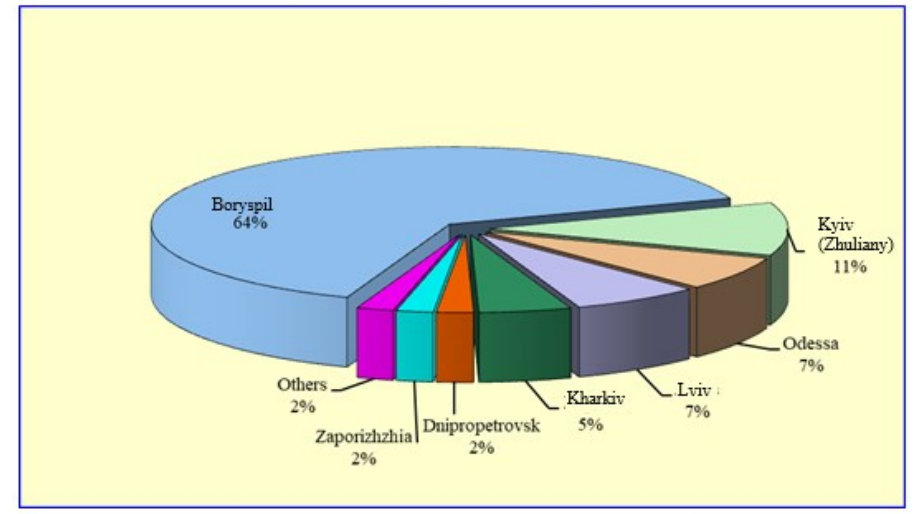

Fig. 3. Pitoma of the carriage of provincial airports in the foreign services of passengers for 2021

In recent years, there has been a tendency to increase passenger traffic at Ukrainian airports, and airport complexes are becoming major financial regulators and infrastructural elements of territorial development. Figure 4 shows the dynamics of passenger traffic at regional airports in Ukraine from 2009 to 2019 (Boyko, 2018). The pandemic has made adjustments to the volume of passenger traffic - therefore, the period 20202021 is not considered in this study.

In recent years, there has been a tendency to increase passenger traffic at Ukrainian airports, and airport complexes are becoming major financial regulators and infrastructural elements of territorial development (Boyko, 2018).

The annual result of the central air gates of Ukraine is in the region of the 50th place among European airports. Boryspil's neighbours are the airports of such cities as Stuttgart (Germany), Porto (Portugal), Venice (Italy) and Lyon (France). London`s Heathrow traditionally remains the European leader, with about 78,000,000 people using its services. In total, the first place in the world has long been occupied by the Hartsfield-Jackson Atlanta International Airport in Atlanta (USA); in 2019, 104 million passengers passed through it (Boyko, 2018).

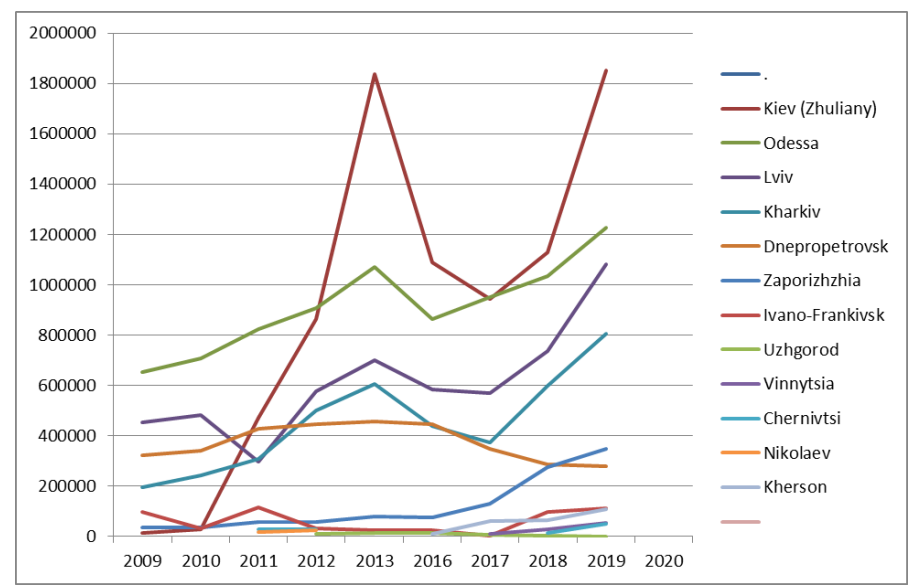

Fig. 4. Passenger traffic of Ukrainian airports for 20092019 (since March 2020, the information is approximate, so the authors did not refer to it) 
The trend in the quantitative indicators of airports should not affect the quality and variety of travel services. On the contrary, national airports can increase the volume of passenger traffic. In order to bring regional airports to international standards, Ukraine adopted the State Target Program for the Development of Airports until 2023 (Ministry of Infrastructure of Ukraine, 2020) and the Aviation Transport Strategy of Ukraine until 2030 (State Aviation Administration of Ukraine, 2018). The programs are aimed at meeting the needs of the state in ensuring the stable development of the aviation industry, bringing aviation transport in line with international standards, ensuring that Ukraine acquires the status of a transit state, taking into account its unique geographical location, increasing the efficiency of state property management, introducing modern information technologies (UNWTO Tourism Highlights, 2018).

Of course, a logical question arises about the social support of airlines regarding the financing of air travel for passengers with disabilities or those belonging to the categories of inclusive tourists (Fig. 1), which we propose in the form of the second financial aspect, or rather state subsidies, which allows in different percentages to compensate for the costs of special servicing inclusive passengers both at the airport and onboard.

Due to differences in the economic conditions for performing various types of air transportation, deregulation practices should reflect the problems of both civil aviation in general and the problems of lowintensive passenger traffic on airlines serving remote, sparsely populated areas.

This approach required the legislative consolidation of the Public Service Obligation (PSO) system - a system of airlines' obligations to carry out state-subsidised «necessary» (socially significant) air transportation, ensuring the implementation of «equal» rights and opportunities for citizens of any country. Such a document in the EU is the act of the Council of Europe No. 2408/92 of 23.07.1992 «On access for air carriers of the European Community to domestic air routes» (Le, 2011).

In order to motivate a commercial carrier to transport people with disabilities and inclusive passengers by air, it is necessary to propose a range of measures to stimulate it to carry out air transportation, referred to the social network of airlines EAS (Essential Air Service). This is the segment of "essential" air travel, operating under special rules under the PSO's system of obligations. According to similar but not uniform rules, these shipments are supported by the state or regional authorities of different countries, based on local circumstances.

Interesting in this regard is the practice of the United States, Australia and Canada, as states that have significant PSO funding and the size of the EAS network, to a large extent functioning in northern, remote regions with an underdeveloped network of land transport communications.

For example, in Australia, up to $75 \%$ of local air travel is carried out using government support (subsidies equal to $45 \%$ of the value of the commercially reasonable fare). The same subsidising approach is typical for a number of socially important airlines in Alaska, USA, where the size of federal government subsidies is about $\$ 140$ million per year. The practice of Canada, for example, is interesting in that one of the main directions in the state and regional policy for the development of local air transportation is the support of small airports (Zapesotsky, 2012).

Elsewhere in the world, the PSO system has a limited nature, mainly aimed at maintaining separate airlines to the island parts of the state. In the UK, the EAS network includes 16 airlines serving routes within Scotland. Portugal subsidises routes from the mainland to the Azores and Madeira, Spain supports routes to the Canary Islands. Norway - routes connecting the center with the remote regions of the west and north of the country (Nechiporuk, 2019).

Having proposed a simple analysis of international experience in the procedure for subsidising air transportation, two main conclusions can be drawn:

1. Subsidising air travel is closely related to solving the state's social problems to ensure transport accessibility of the population for travel. Subsidies are implemented on an integrated basis - primarily through two main funding channels - air carriers operating flights on socially significant routes and airports.

2. Mechanisms of budget subsidies, as a rule, work effectively only when priorities of national interests are formulated at the state level, a balance of interests covering the spheres of interaction between air carriers, airports and passengers (tourists) is maintained.

A study of the situation on the market of regional and local air traffic in Ukraine showed the following critical factors:

1. Regional airlines have insufficient funding.

2. The aircraft fleet is morally and physically obsolete.

3. The regional network of airports has been significantly reduced.

4. The ageing of flight and technical personnel of regional airlines is going on, a shortage of new generation pilots will be felt.

5. Low salaries in regional airlines cannot keep young professionals and stop staff drain.

6. The chain of incentives for regional and local flights in airport tariffs and charges, payment for meteorological support, and the cost of jet fuel is practically non-existent. The main principle of improving the system of measures of state support for regional air transportation in the current state of the Ukrainian air transport market, in our 
opinion, is to maintain a single strategy of action, the application of uniform standards to all subjects and participants in the technological chain of the transportation process, which can be presented in the form of a block diagram (Fig. 5).

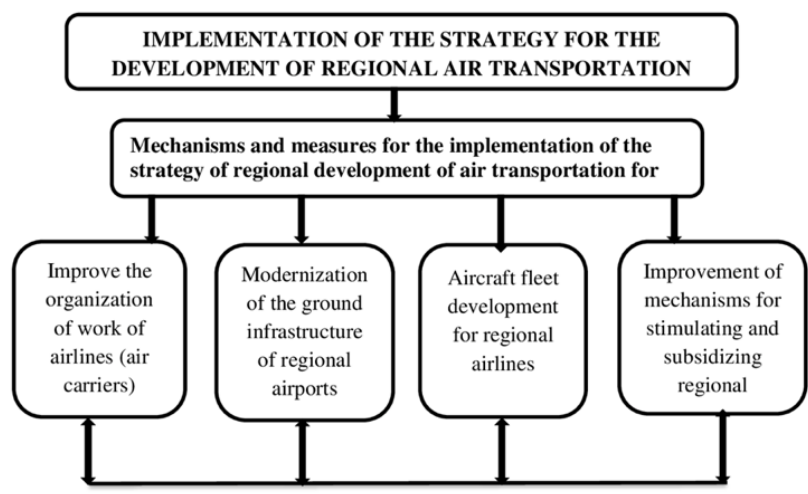

Fig. 5. Block diagram of the implementation of the strategy for the development of regional air transportation in Ukraine

Airlines must assist passengers with disabilities to provide passengers with disabilities with clear guidance regarding their requirements for the carriage of mobile devices and medical equipment in a manner that considers the interests of passengers, relevant safety regulations and real operational capabilities. At the same time, the national legislation of the carrier countries should be balanced in its application and should not impose excessive or unattainable tasks on airlines.

An important aspect of air transport operation is the coordination of stakeholders of their transport rules. Furthermore, it approaches its implementation to ensure a consistent, integrated service for passengers with disabilities, regardless of their location and national borders.

Consequently, it will be relevant to develop a coherent, logical and compromise approach based on mutually agreed principles within the study issue, which will bring significant benefits to inclusive passengers, including passengers with disabilities and the aviation industry itself. Such approaches include:

a) increasing the availability of air travel worldwide for inclusive people in general and people with disabilities in particular.

b) Harmonisation of national policies of different countries, which will be able to provide diversified information support to inclusive tourists in domestic and international travel.

c) They are avoiding situations of operational complexity and additional costs for airlines.

d) The aviation industry's contribution to the achievement of the UN Sustainable Development Goals so that no individual or country is left behind.

\section{Conclusions and Recommendations}

Based on the international experience, the following conclusions can be drawn:

1. Subsidising air travel in the northern and remote territories ensures equal civil rights of the population to move regardless of residence (social task). (Skryleva, 2018)

2. Budget subsidies for airports with low flight intensity, but socially significant, is effective when the state clearly defines the priorities of public needs and the interests of air carriers, airports and users.

3. In Ukraine, at the moment, there are various measures of state support for regional aviation. Subsidies are distributed in the following areas:(Skryleva,2018)

- Support of domestic manufacturers of regional aircraft (including an important factor guarantees of after-sales service),

- Subsidising of airlines' expenses when paying lease payments for regional aircraft,

- Financing of small regional airports and landing sites in remote and inaccessible territories, united in enterprises of different forms of ownership, subsidising and co-financing of socially significant flight routes.

4. An important trend in supporting regional transportation is the participation of the Administrations of the constituent entities of Ukraine in sharing the financial burden with air carriers serving the territories of these entities.

5. To carry out, within the framework of the regulatory framework for subsidising, the division of regional transport into social and commercial, differing in terms and mechanisms of subsidising:

- Socially significant transportation is carried out in hard-to-reach territories that do not have year-round ground communication in order to ensure transport accessibility of the population with a low effective demand;

- Commercial (competitive) air transportation is developing in a year-round competition with land transport to attract an active part of the population, ready to pay extra for the speed of transport communication, temporary state support for «rolling» routes.

6. Adopt the developed regulatory documents that regulate the comfortable conditions of air travel for people with disabilities and passengers of other inclusive categories. For people with disabilities, such living conditions must be created that will allow them to lead an active social life with a minimum of their own efforts and costs aimed at compensating for their physical disabilities, as well as in the absence of unreasonable administrative and economic barriers generated by their disability or delusions of society. 
Studying, discussing and developing promising solutions regarding urgent problems in the tourist transport infrastructure will help to smoothly reorganise the basic plans, strategies, prospects for providing comfortable transport services for the transportation of inclusive air passengers.

\section{CRediT author statement}

Natalyya Bielousova: Conceptualisation, WritingOriginal draft preparation, Investigation, Supervision, Validation, Writing - Review Editing Olha Lyubitseva: Methodology, Visualisation, Investigation Olha Skorostetska: Software, Investigation, Validation, Writing Review Editing Elena Boiko: Data curation, Writing- Original draft Preparation, Formal analysis, Validation, Writing - Review Editing.

\section{References}

Airbus. (2019, August). Global Market Forecast: 20192038. Retrieved November 2nd, 2019, from https://www.airbus.com/content/dam/corporat e-topics/strategy/global-marketforecast/GMF2019-2038-Airbus-CommercialAircraft-book.p

AON. (2020). Cut-e: Talent Assessment for Aviation. Retrieved 25 February, 2020, from https://assessment.aon.com/enus /assessmentsolutions/assessing-for-theaviation-s.

Bielousova N. and Skorostetska O. (2020). Development of inclusive tourism in Ukraine. Current issues of inclusive tourism introduction in Ukraine and other countries: collective monograph/ - Poznan, - pp. 36-52

Boiko, O. and Prusov, D., (2018), Prerequisites for the integrated geoinformation systems implementation for spatial planning of airport complexes. Proceedings of the National aviation university, 4(2018), pp.39-46. Doi: DOI: 10.18372/23061472.77.13496

Bielousova N. V., (2017), «Inclusive tourism» or «travel without barriers» in modern society Ukraine: geographical analysis and search for solutions to materials: VII International Scientific Conference, m. Kherson, 5-6 October 2017 [edited by I.Pylypenko By D Malchykovoyi]. (Kherson: Publishing House «Helvetica») p.33-35

Bielousova N. V. (2018) Theoretical aspects of the development of inclusive rehabilitation and social tourism in Ukraine. Scientific journal «Scientific notes of Sumy State Pedagogical University. Geographic Sciences». (Sumy: Sumy MPU named after A S Makarenko) p. 205-213

Bielousova, Natalia, (2019), Actual Problems of Inclusive
Tourism in Ukraine, Social work and social education, 3(2019), pp. 15-25. Doi: 10.31499/.3.2019.190393.

Convention on the Rights of Persons with Disabilities (2006). Chicago. Retrieved April 12nd, 2021, from https://www.un.org/ru/rights/disabilities/about _ability/inbrief.shtml

Le Man, T., (2011), Foreign experience and forms of government support for social significant traffic on Aviation. "Practical Marketing", 2 (168). pp. 33-36.

Nechiporuk N.M., Kizima M.I. (2019). Inclusive tourism beyond the cordonю. Strategic perspectives of tourism, hotel and restaurant Industry in Ukraine: theory, practice and innovation development. Uman, (30-31.10.2019). - p. 128-130.

Skryleva E., Red Wings airlines employee (tarih yazmiyor), available at: https://www.morvesti.ru/izdaniya/tdr/archive/ 2018/06.php?cv=1

State Service of Ukraine (SSU) - Department of Aviation Services of Ukraine for (2017). Retrieved April 12nd, 2021, from https://avia.gov.ua.

UNWTO Tourism Highlights (2018), UNWTO Tourism Highlights: 2018 Edition. World Tourism Organization (UNWTO). doi: 10.18111/9789284419876.

Konanova, E. I., (2019), Inclusive tourism: technology and organisation of a tourist product, South Federal University, p.129 URL: https://biblioclub.ru/index.php?page=book\&id=57 7840 (date of access: 06/08/2021). - Bibliography: pp. 112-119.- ISBN 978-5-9275-3164-6.

Mezhevaya L. A., Letin A. L., Lugovskaya L. A., (2015), Theory and practice of organising inclusive tourism in Russia, Modern problems of science and education. 1(1), URL: http://www.scienceeducation.ru/ru/article/view?id=17354 (date accessed: 06/08/2021).

Ministry of Infrastructure of Ukraine, M. (2020) Mukachevo Airport Construction Project. Available at:

https://www.kmu.gov.ua/en/news/mininfrastru kturi-proekt-budivnictva-aeroportu-v-mukachevivklyucheno-do-derzhavnoyi-cilovoyi-programirozvitku-aeroportiv (Accessed: 26 June 2021).

Naumenko, L. Yu., Lepsky, V. V., Makarenko, S., Borisova, I. S., Semenenko, A. V., (2015), Inclusive tourism as a type of rehabilitation: modern needs of people with disabilities, Ukrainian Bulletin of Medical and Social Expertise, 2(2015), pp. 23-26. ISSN 2224-0454 (date accessed: 08.06.2021).

Yun G. M., Marintseva K. V., (2014), Decomposition of the network of air routes, Science-Intensive Technologies, 2(2014), pp.219-222. Url: 
http://nbuv.gov.ua/UJRN/Nt_2014_2_14 (date accessed: 08/06/2021).

Zaporozhets O. I., Synylo K. V., (2012), Information technology for security and environmental protection at airports, Scientific bulletin of the Kherson State Maritime Academy, 8(2012), pp.138147.

Zaporozhets O. I., (2014), GIS-monitoring of the environment in airport , Bulletin of the Kherson State Maritime Academy, 10(2014), pp.268-275. Url: http://nbuv.gov.ua/UJRN/Nvkhdmi_2014_1_38, date accessed: 08/06/2021)

Zapesotsky, A. S., (2012), Strategic marketing in tourism: theory and practice, SPbGUP Press, p.152. 